\title{
LAGU TIAS DALAM UPACARA PERNIKAHAN ADAT SIMALUNGUN \\ DI DESA BANGUN PURBA (STUDI \\ KAJIAN, BENTUK PENYAJIAN, FUNGSI \\ DAN MAKNA LAGU)
}

\author{
Eko Putra Oktavianus
}

Prodi Pendidikan Musik

\begin{abstract}
Eko Putra Octavianus. Nim 209342040 "Songs Tias in Simalungun traditional wedding ceremony in the village bangun purba (Studies of studies, forms of presentation, function and meaning of the song)". This study aims to find out about the song tias of form of presentation, function and meaning of the song in the wake of early marriage ceremonies. This study is based on a theoretical foundation to explain the meaning assessment form, function and meaning of the song. This research was conducted in the village bangun purba, during the wedding ceremony Simalungun. Data collected through literature study, observation, interviews, and documentation. This research was seen at the beginning of the event to completion, with the aim of seeing the form of presentation, function and meaning of the song in the traditional Simalungun. The function of this song was made to entertain the "boru" who come to the party "Tondong" which was performed during traditional wedding ceremony Simalungun wherever they are, including in the village bangun purba. And at the same time see how the lives of people in the village get up early, and some clans in the area woke up early. This song has a meaning about a boy who had changed when he married them. The song is sung by a singer in the show, which is accompanied by some traditional musical instruments Simalungun
\end{abstract}

Keywords: Songs Tias, tools - musical instruments Simalungun 


\section{PENDAHULUAN}

Ragam dari kebudayaan yaitu sistem religi dan upacara keagamaan, sistem dan organisasi kemasyarakatan, sistem pengetahuan, bahasa, kesenian, system mata pencaharian hidup, dan system teknologi dan peralatan.Salah satu bagian dari kebudayaan yang sangat berperan adalah musik tradisional yang merupakan kekayaan budaya nasional yang tetap harus dijaga kelestariannya.Guna melestarikan kebudayaan daerah sebagai aset kebudayaan nasional hendaknya dapat digali dan dikembangkan.Musik tradisional merupakan bagian dari upacara adat sebagai perangkat yang memiliki tatanan atau aturan khusus sesuai kebutuhan ritualnya.Disamping itu musik tradisional merupakan unsur budaya penting. Karena, musik tersebut merupakan alat untuk menyampaikan hal yang akan dan telah terjadi dalam kebudayaan itu sendiri.

Musik merupakan bunyi yang terorganisir dan tersusun menjadi karya yang dapat dinikmati oleh manusia. Musik memiliki bentuk dan struktur yang berbeda-beda dan bervariasi.Bentuk dan struktur yang bervariasi, membuat musik menjadi seni yang terbatas,artinya bahwa musik menjadi wadah untuk mengekspresikan segudang ide-ide kreatif para pecinta seni khususnya seni musik.

Setiap jenis-jenis musik pasti memiliki spesifiknya masingmasingseperti musik pop, jazz, rock, blues, keroncong, dangdut, klasik, bahkan musik tradisional juga memiliki ciri khas tersendiri baik dari segi alatalat musiknya, alirannya maupun cara penyajiannya. Bentuk musik jazz terkenal dengan perpindahan/progress akordnya, musik rock yang biasanya selalu beraliran keras, musik klasik yang kental dengan notasi, sedangkan bentuk musik tradisional yang identik dengan nada-nada pentatonik dalam penyajiannya, dan begitu juga dengan jenis-jenis musik lainnya.

Musik tradisional merupakan musik khas suatu daerahatau suku tertentuyang secara turun- temurun dilestarikan dan menjadi sebuah kebudayaan. Setiap daerah atau wilayah regional memilki musik tradisionalnya masing-masing seperti Jawa, Bali, Melayu, Dayak,Melayu, Toraja, Betawi, Batak dan lainnya.

Tidak mengherankan jika ada dua daerah yang memiliki musik 
tradisional yang sama baik dari segi alat musiknya, maupun dari cara penyajiannya. Itu terjadi karena dua daerah tersebut merupakan keturunan dari nenek moyang yang sama. Jawa dan Bali memiliki musik tradisional yang sama yaitu gamelan, akan tetapi bentuk dan struktur penyajiannya berbeda-beda.

Di Sumatera utara, setiap suku memilki musik tradisionalnya masingmasing. Ada yang sama dari segi alat musiknya, dan juga dari segi penyajiannya, seperti suku Batak. Suku Batak merupakan suku yang terdiri dari enam sub-etnis, yaitu Toba, Simalungun, Karo, Pakpak, Mandailing, dan Angkola Sipirok. Dalam kehidupan sehari-hari banyak orang mengasosiasikan kata "Batak" dengan 'orang Batak Toba' karena dari keenam Sub-etnis Batak, Batak Toba yang paling besar jumlahnya. Hal ini dapat dilihat dari segi jumlah masyarakatnya, kebudayaannya maupun dari segi tradisi turun temurun.

Musik telah ada sejak manusia mengenal peradaban.Setiap budaya di dunia ini memiliki musik yang khusus diperdengarkan atau dimainkan berdasarkan peristiwa-peristiwa bersejarah dalam perjalanan hidup anggota masyarakat.Pada umumnya manusia memiliki rasa senang untuk mendengarkan musik, kendati tingkat kesenangan antara satu dengan yang lainnya berbeda-beda.Oleh karena itu, rasa senang terhadap musik tidak dapat dianggap sifat khas atau suatu keanehan yang kebetulan dimiliki seseorang. Rasa senang mendengar musik disebabkan oleh beberapa faktor seperti : respon terhadap kesan irama, melodi, harmoni, warna suara, dalam suatu komposisi serta faktor penggunaan teks/syair bila sebuah komposisi yang didengar itu berbentuk nyanyian.

Budaya adalah suatu cara hidup yang berkembang dan dimiliki bersamasama oleh sebuah kelompok manusia yang diwariskan secara turun-temurun dari generasi ke generasi yang selalu dipengaruhi oleh norma adat-istiadat yang berlaku dalam masyarakat. Musik sangat penting dalam kebudayaan.Musik adalah salah satu media ungkapan kesenian, musik mencerminkan kebudayaan masyarakat pendukungnya. Dalam musik terkandung nilai dan norma-norma yang menjadi bagian dari proses enkulturasi budaya, baik dalam bentuk formal maupun informal. Musik dapat dipergunakan pada acara adat, 
seperti upacara religi, pernikahan, mengiringi tari-tarian, hiburan, serta memanggil roh leluhur dan lain sebagainya. Dalam kegiatan adat, musik merupakan bagian dari tradisi. Tetapi tidak semua kegiatan adat menggunakan musik, akan tetapi ada kegiatan adat yang tidak terlepas dari elemen musik. Musik adalah cetusan ekspresi perasaan atau pikiran yang dikeluarkan secara teratur dalam bentuk bunyi.Bisa dikatakan, bunyi (suara) adalah elemen musik paling dasar.

Suara musik yang baik adalah hasil interaksi dari tiga elemen, yaitu: irama, melodi, dan harmoni. Irama adalah pengaturan suara dalam suatu waktu, panjang, pendek dan temponya, dan ini memberikan karakter tersendiri pada setiap musik. Melodi adalah susunan nada yang diatur tinggi rendahnya, pola, dan harga nada sehingga menjadi kalimat lagu. Melodi merupakan elemen musik yang terdiri dari pergantian berbagai suara yang menjadi satu kesatuan, di antaranya adalah satu kesatuan suara dengan penekanan yang berbeda, intonasi dan durasi yang hal ini akan menciptakan sebuah musik yang enak didengar. Sedangkan harmoni adalah ilmu yang mempelajari tentang penggunaan nada secara serentak / bersamaan. Kombinasi beberapa tinggi nada dan irama akan menghasilkan melodi tertentu. Selanjutnya, kombinasi yang baik antara irama dan melodi melahirkan bunyi yang harmoni.

Daerah Sumatera Utara memiliki ragam kebudayaan termasuk seni musik tradisionalnya yang berbeda-beda sesuai dengan etnisnya masing-masing. Salah satu etnis terdapat di Sumatera Utara adalah Etnis Simalungun yang dimasukkan sebagai bagian dari etnis Batak Toba, Mandailing, Pak-pak dan Karo.

Sistem kekerabatan yang dimiliki oleh masyarakat Simalungun adalah berdasarkan pada prinsip Tolu Sahundulan dan Lima Saodoran. Tolu Sahundulan terdiri dari Tondong (kelompok kerabat istri), Sanina (sanak saudara satu keturunan/marga), anak boru (pihak ipar). Dalam pengaturan tempat duduk (parhundulan) pihak dari sanina di "jabu bona" (sebelah kanan rumah), pihak kelompok tondong disebelah kanan pihak sanina, dan pihak anak boru disebelah kanan pihak tondong.Itulah sebabnya dikatakan tolu 
sahundulan (pengaturan tempat duduk dalam tiga kelompok).

Lima saodoran ialah kerabat keluarga luas yang merupakan gabungan dari seluruh lembaga adat. Hal ini terjadi pada upacara besar dan luas. Jadi pengertian lima di sini ialah yang dihadiri oleh lima kelompok kerabat yang terdiri dari tondong (kelompok istri), sanina (sanak saudara satu ke turunan/ marga), anakboru(pihakipar), tondongni tondong (kelompok pemberi istri kepada tondong), anak boru mintori (kelompok boru dari ipar). Masyarakat Simalungun memandang diri mereka sebagai suatu kelompok etnis yang kuat yang dipersatukan oleh bahasa, musik tradisional, serta adat-istiadat dan kekhasan yang unik yang ada pada budaya masyarakat Simalungun

Dengan adanya kegiatan ini sistem kekerabatan masyarakat Simalungun akan terjalin harmonis, karena disanalah para penatuah-penatuah adat bertemu dan saling beradu komentar agar menuju Kabupaten Simalungun yang maju dalam bidang sektor apapun.Lagudanmusikdaerah yang tentu saja merupakan kekayaan bangsasudah seharusnya dilestarikan dan dikenalkan keseluruh warga negara Indonesia. Bukanhanya sekedar mengetahui dan memahami keanekaragaman budaya, tapi yang lebih penting adalah mengkokohkan persatuan dan kesatuan bangsa. Lagu merupakan syair-syair yang dinyanyikan dengan irama yang menarik agar menjadi enak didengar. Merupakan lagu bahan seni nada atau suara dalam urutan, kombinasi, dan hubungan temporal (biasanya diiringi dengan alat musik) untuk menghasilkan lagu bahan musik yang mempunyai kesatuan dan kesinambungan (mengandung irama). Sedangkan ragam nada atausuara yang berirama disebut juga dengan lagu. Lagubisa menjadi media curahan hati orang yang membuat lagu itu tadi. Sehingga lagu yang dinyanyikan bisa bernuansa sedih, senang, maupun jenaka. Jadi sebuah lagu dapat diartikan sebagai sebuah ungkapan yang dikeluarkan oleh sebuah nada atau bunyian dan dalam sebuah lagu dapat diambil kesimpulan yang ada pada lirik lagu tersebut. Maka untuk itu penulis mengambil judul

"Lagu Tias Dalam Acara Pernikahan Adat Simalungun Di Desa Bangun 
Purba (Studi Kajian Bentuk Pernikahan Adat Pada Masyarakat Penyajian, Fungsi dan Makna Lagu)". Simalungun di Desa Bangun Purba" Tujuan penulisan yang ingin daerah Bangun Purba. Waktu penelitian dicapai dalam penulisan ini adalah :

1. Untuk mengetahui peranan dan proses penelitian dilaksanakan pada bulan Juni - Agustus 2015.

Lagu Tias dalam upacara pernikahan adat pada masyarakat Simalungun di Desa Bangun Purba

2. Untuk mengetahui Bentuk, Fungsi dan Makna Lagu Tiasdalam upacara pernikahan adat pada masyarakat Simalungun di Desa Bangun Purba

3. Untuk mengetahui latarbelakang dibawakannya Lagu Tias dalam upacara pernikahan adat pada masyarakat Simalungun di Desa Bangun Purba

4. Instrumen apa saja yang digunakan untuk mengiringi Lagu Tias dalam upacara pernikahan adat pada masyarakat Simalungun di Desa Bangun Purba

\section{Lokasi dan Waktu Penelitian}

Sesuai dengan judul penelitian "Peranan Lagu Tias Dalam Upacara

seluruh pemain musik tradisional
ungun, yang juga sekaligus sebagai

\section{Populasi dan Sampel}

\section{Populasi} Simalungun, yang juga sekaligus sebagai penyanyi, tokoh adat, orang-orang yang menari tor-tor (manortor) danpengantin

\section{Sampel}

seluruh pemain musik tradisional, yang juga sekaligus sebagai penyanyi, tokoh adat, orang-orang yang menari tor-tor (manortor) danpengantin, adalah sebanyak 15orang, yang terdiri dari:

1. Pengantin (laki-laki dan perempuan) 2 (dua) orang

2. Tokoh adat Simalungun 3 (tiga) orang

3. Pemain Musik Tradisional 5 (lima) orang

4. Orang-orang yang menari tor-tor (manortor) 4 (empat) orang

5. Penyanyi Lagu Tias 1 (satu) orang 


\section{Teknik Pengumpulan Data}

Teknik pengumpulan data yang dilakukan adalah sebagai berikut:

1. Observasi

2. Wawancara

3. Dokumentasi

4. StudiKepustakaan

\section{Teknik Analisis Data}

Dalam penelitian ini data yang digunakan adalah teknik analisis data kulitatifdimanaproses mencari dan menyusun secara sistematis data-data yang diperoleh dari hasil wawancara, catatan lapangan, dan dokumentasi.

ISI

Lagu Tias merupakan lagu yang dimain pada saat upacara pernikahan masyarakat Simalungun di Desa Bangun Purba dan disertai oleh musik tradisional berperan sebagai pengiring tarian (tortor) pada saat pelaksanaan upacara adat dan merupakan bagian yang membantu menyempurnakan berjalannya adat pada masyarakat dalam tradisi ada Simalungun. Lirik atau teks nyanyiannya adalah bagian yang sangat penting dari lagu Tias tersebut, karena merupakan semacam narasi tentang orang atau tokoh yang sedang melaksanakan tarian adat (manortor) dalam mengiringi rangkaian penghormatan kepada orangtua mempelai. Teks dari Lagu Tias tersebut juga sifatnya sangat kontekstual. Dalam arti harus benar-benar sasuai dengan berbagai aspek yang menyangkut diri atau tokoh yang sedang melaksanakan tarian adat (manortor). Dari sifatnya yang demikian itu muncul isi teks Lagu Tiasberupa penjelasan tentang upacara adat, puji-pujian, nasehat dan doa selamat, ajaran moral serta cerita tentang kehidupan yang akan datang untuk pengantin.

Lagu Tias yang dinyanyikan dalam pengiring orang-orang atau keluarga dengan mempelai, pada saat manortortidak berbeda antara satu dengan yang lainnya. Peran Lagu Tias dalam upacara pernikahan masyarakat Simalungun di Desa Bangun Purba, terletak pada saat kedatangan keluarga dan memberi penghormatan. Selanjutnya proses penyambutan keluarga yang datang dilakukan dengan menggunakan adat seperti sebelumnya. Penyambutan ini dilakukan untuk menghormati tetuah adat atau keluarga yang lebih tua, karena adat masyarakat Simalungun khususnya di Desa Bangun Purba sangat kental dan menjaga norma adat secara turuntemurun. 
Peranan lagu Tias pada acara pernikahan masyarakat Simalungun sangat berpengaruh, mengingat lagu tersebut memuat makna dan pesan moral yang dibangun untuk mengingatkan pada pengantin agar menjaga hubungan rumah tangga, mengingatkan akan aturan dan hakikat dalam hubungan rumah tangga.

Lagu Tias juga berisikan syair-syair yang merupakan penjelasan maksud upacara, yang ditujukan kepada kerabat yang hadir. Apabila ditinjau dari kata yang terdapat pada bagian ini, maka Lagu Tias berperan sebagai penyambung lidah panortor (suhutsiha bolonan) guna menjelaskan maksud dari upacara tersebut, sehingga dari isi bagian ini orang dapat lebih banyak mengetahui tentang maksud upacara yang sedang dilaksanakan. Lagu Tias dalam menyampaikan penjelasan tersebut, sudah tentu akan menyesuaikan syairnya dengan upacara yang sedang dilaksanakan. Dalam upacara perkawinan, Lagu Tias akan menjelaskan bahwa pelaksanaan upacara itu adalah untuk menyambut menantu perempuan mereka atau menyambut pengantin. Dalam penjelasan tersebut Lagu Tias akan menceritakan pula identitas dari masing-masing pengantin, seperti pengantin itu berasal dari marga apa, anaknomor berapa, dan tempat tinggalnya dimana. Isi bagian syair ini selalu ditampilkan pada setiap Lagu Tias. Apabila ditinjau dari arti kata dalam syairnya, maka fungsi dari bagian nyanyian ini merupakan suatu penjelasan untuk memperkenalkan si panortor kepada seluruh kerabat yang hadir, ini dilakukan agar darisana orang dapat mengetahui dan bagaimana hubungan si panortor terhadap pihak suhut sihabolonan, sekaligus juga orang menentukan tuturnya (kedudukan) dalam peradatan. Adapun makna yang terkandung di dalam syair Lagu Tias:

1. Pujian,

Bagiansyair yang berisikan katakata pujian juga terdapat pada nyanyian Lagu Tias. Isi pujian ini ditujukan kepada setiap yang manortor. Dalam penyampaian pujian tersebut, Lagu Tias selalu memperhatikan kedudukan sipanortor, baik dalam peradatan, dalam pekerjaan, atau pun dalam kehidupan sehari-hari. Sama dengan menceriterakan latar belakang panortor, selalu memberikan pujian mengenai halhal yang baik saja. Jika suhu tinantasori pada yang manortor misalnya, maka 
akan memberikan pujian tentang kebijaksanaan sebagai istri atau kepandaiannya dalam mendidikanak. Jikatodong yang manortor, maka isi pujiannya akan mengenai kesedian tondong dalam memberikan berkat dan kesediaan tondong dalam menghadiri upacara tersebut. Begitu pula kalau anak boru yang manortor mata kata pujian yang diberikanakan mengenai kerajinan mereka dalam membantu pelaksanaan pekerjaan di pesta tersebut.

\section{Nasehat,}

Dalam nyanyian Lagu Tias terdapat juga bagian yang berisikan nasehat. Nasehat ini ditujuakan kepada pihak panortor. Isi nasehat yang disampaikan Lagu Tias tentu saja harus disesuaikan dengan kedudukan yang manortor. Misalnya jika pihak suhut yang manortor, isi nasehat yang disampaikan padanya adalah untuk mengingatkan pihak suhut agar tidak juga mengucapkan syukur kepada Tuhan atas terlaksananya upacara tersebut. Jika pengantin yang manortor, maka isi nasehat yang diberikan ialah untuk hidup seia-sekata, sepenanggungan, baik dalam suasana duka maupun suka.
3. Doa,

Dalam nyanyian Lagu Tias terdapat juga bagian yang berisikan doa, untuk meminta perlindungan kepada Tuhan, meminta agar diberiumur yang panjang, diberikan kesehatan, dan meminta rejeki yang baik dalam kehidupannya. Bagian doa ini ditampilkan pada setiap penampilan gondang, ditujukan kepada setiap panortor dan kepada kerabat yang hadir. Dalam penyampain doa ini kadang-kadang Lagu Tias berperan sebagai wakil dari yang manortor, dalam meminta perlindungan pada Tuhan, kadang-kadangia berperan sebagai wakil dari seluruh kerabat yang hadir, yakni pada waktu menyampaikan doa yang ditujukan pada pihak suhut sihabolonan dan kedua pengantin.

Dalam Lagu Tias terdapat juga bagian yang menceritakan latar belakang dari setiap panortor kepada seluruh kerabat yang hadir. Cerita ini hanyalah mengenai hal yang baik-baik saja, sedangkan hal yang tidak baik mengenaipanortor tidak pernah diceritakan. Adapun ceritera latar belakang yang akan disampaikan adalah mengenai identitas dan keberhasilan dari setiap panortor, misalnya, kedudukan si panortor di dalam pesta itu sebagai apa, 
berasal dari marga mana, dan kedudukannya di tengah-tengah masyarakat dan lain-lain.

Masyarakat yang bermukim di Desa Bangun Purba merupakan asli suku batak Simalungun yang menerapkan sistem keakaraban yang kental tanpa memandang buluh suku lain yang masuk kedaearah tersebut. Musik Tradisional Simalungun sangat dipelihara agar nilainilai kebudayaannya tidak hilang. Salah satu contoh bahwa musik tradisional simalungun yang dipelihara sampai sekarang adalah dalam acara pesta Pernikahan karena merupakan acara ritual adat. Adapun pembagian instrument musik simalungun dapat dilihat seperti gambar dibawah :

1. Golongan Idiofon

1. Mongmongan dan Ogung

Mongmongan merupakan alat musik yang terbuat dari kuningan atau besi yang memiliki pencu. Mongmongan ada dua macam yaitu, Mongmongan sibanggalan dan Mongmongan sietekan. Dan mongmongan ini dipergunakan dalam seperangkat gonrang sidua-dua dan gonrang sipitu-pitu/ gonrang bolon. Mongmongan dapat juga dipergunakan untuk memanggil massa di suatu desa.
Dan Ogung, merupakan nama lain dari gong yang selama ini kita kenal. Ogung ada dua macam yaitu ogungsibanggalan dan ogung sietekan

\section{Sitalasayak}

Sitalasayakadalah alat musik yang bentuknya seperti simbal yang ter terbuat dari kuningan atau besi dan terdiri dari dua bilah yang sama bentuknya. Namun Pada saat sekarang sudah jarang dipergunakan dalam seperangkat gonrang.

\section{Garantung}

Garantungmerupakan alat musik yang terbuat dari kayu dan mempunyai resonantor yang juga terbuat dari kayu. Garantung terdiri dari tujuh bilah yang mempunyai nada berbeda.Gerantung biasanya dimainkan sebagai hiburan ketika istirahat di ladang sebagai pelepas lelah dan sebagai bahan pelajaran untuk menabuh gonrang sipitu-pitu/gonrang bolon.

\section{Golongan Aerofon}

a. Sarunei Bolon

Sarunei Bolonmerupakan jenis alat musik tiup yang mempunyai dua lidah (double reed) badannya terbuat dari silastom, nalihnyaq terbuat dari timah, tumpak bibir 
terbuat dari tempurung. Lidah terbuat dari daun kelapa, dan sigumbang terbuat dari bamboo, Sarune bolon dipergunakan sebagai pembawa melodi

\section{b. Sarunei Buluh}

Sarunei Buluhmerupakan jenis alat musik tiup yang yang terdiri dari satu lidah (single reed). Sarune buluh terbuat dari bambu, mempunyai tujuh lobang suara, sebelah atas enam lobang dan sebelah bawah satu lobang.

a. Tulila

Tulilamerupakan sejenis recorder yang terbuat dari bambu, Tulila dimainkan secara vertikal.

\section{d. Sulim}

Sulim merupakan alat musik sejenis flute yang terbuat daribambu.

\section{e. Sordam}

Sordam merupakan alat musik sejenis flute yang terbuat daribambu yang dimainkan miring (oblique flute )

1. Golongan Membranofon

a. Gonrang Sidua-dua

Gonrang Sidua-duamerupakan gendang yang badannya terbuat dari kayu ampirawas dan kulitnya dari kulit kancil atau kulit kambing. Gonrang Sidua-dua terdiri dari dua gendang. b. Gonrang sipitu-pitu/Gonrang bolon

Gonrang Sipitu-pitu/Gonrang Bolon merupakan gendang yang badannya terbuat dari kayu dan kulitnya terbuat dari kulit lembu, kambing, dan kulit kancil. Pada bagian atas terdapat kulit dan pada bagian bawah ditutupi kayu. Gendangnya terdiri dari tujuh buah gendang.

\section{Golongan Kordofon}

a. Arbab

Arbab adalah alat musik yang terbuat dari : tabung resonantordari labu atau tempurung, leher terbuat dari kayu atau bamboo, lempeng atas terbuat dari kulit kanci atau kulit biawak, senar terbuat dari benang dan alat penggesek terbuat dari ijuk enau yang masih muda.

\section{b. Husapi}

Husapi merupakan alat musik sejenis lute yang mempunyai leher. Husapi terbuat dari kayu dan mempunyai dua senar.

Namun akibat perkembangan zaman sekarang instrument tersebut tidak dipergunakan lagi secara menyeluruh karena hadirnya instrument musik luar seperti keyboard yang dapat merangkum seluruh suara alat musik tradisional Simalungun. 
Peneliti mengamati (observasi, pelaksana dan sekaligus pemain Musik 25 juli 2015), Keberadaan Musik Tradisional dalam acara Pesta Tradisional Simalungun Dalam Pesta Pernikahan ini untuk memperoleh Perkawinan adat Simalungun di Desa keterangan tentang Pergeseran Musik Bangun Purba Kabupaten Simalungun, Tradisional Simalungun, Bapak S. pada saat ini sudah mulai dicampur dengan instrument musik asing, yaitu Keyboard akan tetapi musik tradisioanla yang dipakai pada Pesta Pernikahan ini hanya Gonrang Sipitu-pitu, Sulim, dan Mongmongan. Hal ini terjadi sesuai dengan perkembangan zaman, generasi muda lebih megutamakan musik yang lebih menarik dari musik tradisional simalungun yang diwariskan oleh nenek moyang mereka. Masuknya instrument musik luar ini membuat adanya suatu pergeseran musik tradisional simalungun bagi kaum generasi muda. Generasi muda yang tinggal di Desa Bangun Purba Kabupaten Simalungun sebahagian kurang melestaikan adatistiadat yang dari dahulu sudah dibuat oleh nenek moyang mereka. Namun dalam dalam pelaksanaan pesta Pernikahan ini buka berarti nilai musikalitas simalungunnya menjadi berkurang. Setelah melihat adanya suatu pergeseran Musik Tradisional Simalungun maka peneliti menjumpai bapak S. Damanik selaku panitia Damanik terlebih dahulu menerangkan bahwa seiring hadirnya musik modern, bukanlah berarti hilangnya unsur budaya simalungun. Namun hanya untuk memudahkan penempatan instrument saja. Karena dengan adanya instrument Keyboard ini variasi nada-nada musik simalungun akan lebih enak didengar. Disamping itu juga pelaksanaan pesta Pernikahan ini tidak menitikberatkan pada musik tradisional saja, namun alangkah lebih indahnya nilai musik simalungun dicampur dengan musik modern.

\section{PENUTUP}

\section{Kesimpulan}

1. Lagu Tias merupakan lagu yang mengiringi acara adat Simalungun Dalam Pesta Pernikahan Di Desa Bangun Purba Kabupaten Simalungun merupakan salah satu tradisi adat simalungun yang dilaksanakan secara turun-temurun, dimana sebuah aktivitas adat dan religi terdapat dalam pesta ini. 
2. Bentuk Lagu Tias juga berisikan syair-syair yang merupakan penjelasan maksud upacara, yang ditujukan kepada kerabat yang hadir. Apabila ditinjau dari kata yang terdapat pada bagian ini, maka Lagu Tias berperan sebagai penyambung lidah panortor (suhut sihabolonan) guna menjelaskan maksud dari upacara tersebut, sehingga dari isi bagian ini orang dapat lebih banyak mengetahui tentang maksud upacara yang sedang dilaksanakan. Lagu Tias dalam menyampaikan penjelasan tersebut, sudah tentu akan menyesuaikan syairnya dengan upacara yang sedang dilaksanakan. Dalam upacara perkawinan,Lagu Tias akan menjelaskan bahwa pelaksanaan upacara itu adalah untuk menyambut menantu perempuan mereka atau menyambut pengantin. Dalam penjelasan tersebut Lagu Tias akan menceritakan pula identitas dari masing-masing pengantin, seperti pengantin itu berasal dari marga apa, anak nomor berapa, dan tempat tinggalnya dimana. Isi bagian syair ini selalu ditampilkan pada setiap Lagu Tias.

3. Makna dari Lagu Tias menjadi sebuah doa, pujian dan nasehat kepada mempelai yang menikah dan menjadi bagian dari rangkaian kegiatan pesta pernikahan adat Simalungun.

4. Peneliti melihat bahwa Keberadaan Musik Tradisional Dalam mengiringi lagu Tias pada Pesta Pernikahan bukan sekedar pesta biasa saja, namun memiliki makna yang cukup dalam Karena disana terletak suatu tujuan yakni untuk memajukan dan mengembangkan Kesenian Budaya Simalungun.

\section{Saran}

Dari beberapa kesimpulan dari hasil penelitian dan pembahasan, maka dapat diajukan saran-saran sebagai berikut :

1. Melihat Keberadaan Musik Tradisional Simalungun Dalam Pesta Pernikahan memiliki peran yang sangta penting, diharapkan tradisi init tetap dapat dilaksanakan sebagai salah satu 
identitas seni budaya pada masyarakat simalungun

khususnya di Desa Bangun Purba Kabupaten Simalungun.

2. Melihat pengaruh dan dampak perkembangan zaman yang begitu deras mempengaruhi generasi muda untuk berpaling dari tradisi seni budayanya, perlu melakukan pembinaan untuk generasi muda. Generasi muda diharapkan dapat menggali meneruskan tradisi batak simalungun supaya tidak punah, dan tradisi simalungun dapat dilestarikan.

\section{DAFTAR PUSTAKA}

Al-Barry, M. Dahlan Yacub. 2001. Kamus Sosiologi Antropologi. Surabaya : Indah.

Djohan. 2003. Psikologi Musik.Yogyakarta : Penerbit Buku Baik Yogyakarta.

Damanik. Maradona. Deni.2011. Peranan Lagu Tolo Sahundulan Lima Sodoran Dalam Pesta Perkawinan Adat Simalungun Di Desa Simanabun Kecamatan Silau Kahean Kabupaten Simalungun. Medan. Universitas Negeri Medan.

Jansen. Dietrich.2003. Gonrang Simalungun Struktur dan Fungsinya Dalam Musik Simalungun. Medan:Bina Media.
Fiske, John, 2004. CultureAnd Communication Studies, Jalasutra, Yogyakarta.

Hadeli. 2006. Metode Penelitian Kependidikan. Padang. Quantum Teaching.

Mawar, Ika. 2006. Musik Tradisional SimalungunPada Pesta Pernikahan di Desa Sei Buaya KabDeli Serdang. Medan : Skripsi untuk mendapatkan gelar sarjana SI Unimed.

Nasution, Pandapotan. 2005. Adat Budaya Mandailing dalam Tantangan Zaman.

Medan: ForkalaPovinsi Sumatera Utara.

Prinst, Darwan. 2012. Adat Karo. Medan: Bina Media Perintis.

Simanungkalit. $\quad$ Nortier. 2008. TeknikVokal. Jakarta :Gramedia Pustaka Utama.

Kurniawan. 2001. Semiologi Roland Barthes, Yayasan Indonesia, Magelang.

SutanTinggi, Ch. 2012. SuratTumbaga Holing I. Medan: Penerbit Mitra.

Sinaga, dkk. 2005. Upacara Tradisional Yang Berkaitan Dengan Peristiwa Alam dan Kepercayaan Daerah Sumatera Utara, Depdikbud Kebudayaan Daerah, Jakarta. http://id.wikipedia.org/wiki/Lagu 